University of Nebraska - Lincoln

DigitalCommons@University of Nebraska - Lincoln

2018

Bang for the buck: Understanding employee benefit allocations and new venture survival

Jake G. Messersmith

Pankaj C. Patel

Christopher Crawford

Follow this and additional works at: https://digitalcommons.unl.edu/managementfacpub

Part of the Benefits and Compensation Commons, Business Administration, Management, and Operations Commons, Management Sciences and Quantitative Methods Commons, and the Strategic Management Policy Commons

This Article is brought to you for free and open access by the Management Department at DigitalCommons@University of Nebraska - Lincoln. It has been accepted for inclusion in Management Department Faculty Publications by an authorized administrator of DigitalCommons@University of Nebraska - Lincoln. 


\title{
Bang for the buck: Understanding employee benefit allocations and new venture survival
}

\author{
Jake G. Messersmith \\ University of Nebraska-Lincoln, USA \\ Pankaj C. Patel \\ Villanova University, USA \\ Christopher Crawford \\ Ohio University, USA
}

Corresponding author: Jake G Messersmith, Department of Management, University of Nebraska-

Lincoln, 1240 R Street, Lincoln, NE 68588, USA. Email: jmessersmith2@unl.edu

\begin{abstract}
Providing employee benefits is costly for new ventures, yet offering such inducements is often essential to developing human capital. While a broad combination of employee benefits could yield synergistic effects, adopting a large number of benefits may not be feasible for resource constrained ventures. To ensure survival, while limiting misallocation of scarce resources towards benefits that have lower returns, entrepreneurs must be selective in choosing the benefits that generate the most 'bang for the buck'. Our study assesses the effects of employee benefit offerings on venture survival odds. Based on a longitudinal sample of 1012 US-based ventures from the Kauffman Firm Survey and leveraging, signaling and motivation theories, we find that offering health insurance, flexible work schedules, paid vacation, or paid sick leave increase the odds of survival. However, offering employee stock ownership plans or tuition reimbursement has no significant influence on the odds of survival.
\end{abstract}

Keywords: employee benefits, human capital management, new venture survival

Published in International Small Business Journal: Researching Entrepreneurship 36:1 (2018), pp 104-125.

DOI: $10.1177 / 0266242617717595$

Copyright (C) 2017 Jake G. Messersmith, Pankaj C. Patel, \& Christopher Crawford. Published by SAGE Publications. Used by permission. 


\section{Introduction}

New venture survival and growth are of significant importance to entrepreneurs, policy-makers and scholars around the globe (Ingley et al., 2017; Leitch et al., 2010). The question of new firm survival has been investigated and explained using a host of macro-level forces, including economic conditions and industry structure (Hannan and Freeman, 1989). Other studies have also highlighted the role of resources and capabilities in improving odds of venture survival (Esteve-Perez and Manez-Castillejo, 2008; Koryak et al., 2015; Shepherd et al., 2000; Wright and Stigliani, 2013), but much remains unknown regarding the allocation of resources towards internal human resource (HR) management practices.

This remains an important area of inquiry in the literature, as early investment decisions in HRs are likely to have implications for venture survival and success (Lai et al., 2016). As a result of the synergistic association among HR practices, HR scholars have focused on the joint efficacy of such practices on performance. However, the adoption and implementation of HR practices are costly, and both over-investing and under-investing in such practices could contribute to venture failure. Resource allocation has been theorized to be an important determinant of a firm's survival and development (Barney, 1991; Teece et al., 1997; Zahra et al., 2002), and entrepreneurs themselves are often quick to point to internal resource allocation factors that led to the success or failure of their venture (Zacharakis et al., 1999). Adopting practices that do not influence survival (over-investing) could increase costs for resource constrained ventures. Similarly, not adopting practices that improve odds of survival (under-investing) could also lead to failure. By helping to attract talented HRs, employee benefits play a salient role in both signaling the legitimacy of the new venture to potential employees (Zimmerman and Zeitz, 2002), and also in sorting quality candidates into the recruitment pool. Furthermore, employee benefits help form the early foundation for building more robust systems of high performance work practices (HPWPs). Under-investing in employee benefits could, therefore, limit the development of human capital for early-stage ventures.

Moving from the systemic perspective of HPWPs, we aim to identify the influence of employee benefit practices on venture survival. Extending research linking HPWPs to the success of small and young firms (i.e. 
Messersmith and Guthrie, 2010; Way, 2002), we aim to inform ventures allocating scarce resources towards employee benefits to not only increase the odds of survival but also to avoid implementing benefits that may increase the odds of failure. Therefore, we ask which employee benefit offerings are associated with increased survival odds, and which are more likely to be associated with firm failure?

We draw from existing research to weigh the relative cost of an individual benefit and the likely valence of that benefit in attracting and retaining quality employees. We link employee benefits that have significant potential to aid firms in the attraction and retention of employees, which also carry relatively low costs to new firm survival, while also highlighting the problems associated with costly benefits that possibly are not as highly valued by employees in new ventures. As noted by Coff and Kryscynski (2011), 'the critical path to human capital-based competitive advantage requires attracting, retaining, and motivating employees with valuable human capital at an economic discount relative to competitors' (p. 3). This is particularly important in new ventures, where entrepreneurs may be more concerned about the economic returns of their human capital investments than non-financial benefits that may accrue to employees (Bai et al., 2017). This article helps to provide guidance in this direction and empirically tests the phenomenon of interest. Using a longitudinal sample of 1012 start-ups in the United States (followed from 2004 to 2011) and survival analysis methodology, our findings complement recent work by DeGeest et al. (2015) to suggest that the strategic selection of employee benefits can increase the potential for new firm survival.

This article contributes to existing knowledge in four specific ways. First, previous scholarship on employee benefits in ventures treats all benefits as having similar motivational potential (DeGeest et al., 2015). We examine this assumption more closely to separate those benefits that are likely more attractive to employees from those that fail to motivate, by conceptually analyzing the valence of differing benefit offerings. As new ventures are likely constrained by a lack of resources and a liability of newness (Caves, 1998; Shepherd et al., 2000; Stinchcombe, 1965), employee benefits and rewards need to be scrutinized in regard to both cost and return.

Second, differentiating between effective and ineffective employment benefits could be contingent on firm size. Research in the domain of 
strategic HR management investigates the efficacy of a bundled set of integrated practices that work in concert to improve performance outcomes (DeGeest et al., 2015; Huselid, 1995; Lai et al., 2016; Sheehan, 2013). While this approach has proven beneficial for large firms in a variety of contexts (Jiang et al., 2012), the same may not be evident for smaller or newer ventures (Chadwick et al., 2013). In fact, in an environment of resource constraint, entrepreneurs need to make strategic selection decisions that help overcome the initial liability of newness. Resource orchestration takes on a primary role in determining where to invest scarce resources to maximize survival and success potential (Chadwick et al., 2015). Against this backdrop, this article provides insights about the role of employee benefit offerings, helping to inform the debate surrounding investments in HRs early in a firm's life cycle.

Third, while industry forces are likely to play a significant role in the success or failure of new ventures, internal factors are also likely to affect survival odds. While entrepreneurship research has addressed this in part, through studies of legitimacy (Delmar and Shane, 2004; Zimmerman and Zeitz, 2002) and business planning (Delmar and Shane, 2003), much remains unexplored in this domain. Furthermore, understanding how internal factors relate to the odds of firm survival is an important area of inquiry, as guidance can be provided to entrepreneurs regarding factors that are largely under their control, relative to other environmental forces.

Finally, this article utilizes a unique longitudinal dataset to address the questions of interest. While much of the work on internal HR systems in new ventures is cross-sectional, this article leverages time-lagged data to better understand the factors leading to new firm survival further contributing to small and medium-sized enterprise (SME) research on HR practices (Cardon and Stevens, 2004; Lai et al., 2017; Messersmith and Wales, 2011; Verreynne et al., 2011). Theoretical and practical guidance stemming from such analyses will be useful in continuing to build theories of firm survival.

\section{Literature review and theoretical model}

Existing research has demonstrated that employee benefits have significant, but differential effects on employee attitudes and turnover 
intentions (Blau et al., 2001; Danehower and Lust, 1995). In a study of public sector employees, Ko and Hur (2014) utilize social exchange theory to understand the relationship between employee benefits and attitudinal outcomes. This article finds a positive relationship between the use of both 'traditional' employee benefits and family-friendly benefits and job satisfaction. Furthermore, the authors note that family-friendly benefits are also linked to lower turnover intentions, while traditional benefits were not.

Blau et al. (2001) note that basic or traditional benefit, is linked to lower labor turnover but not necessarily to organizational commitment. Rather, benefits related to career development and enhancement were linked to higher level engagement and participation constructs. These results are echoed by Muse and Wadsworth (2012) who report that traditional benefits programs were not linked to perceived organizational support (POS) in a study of hospital employees, whereas nontraditional benefits did enhance POS. In addition, benefits have been linked to increased motivation for employees, though these increases do not always translate into enhanced productivity (Hong et al., 1995). These findings emphasize that not all benefits are highly valued by employees.

Broadening the scope of discussion, existing work in the field also speaks to the connection between employee benefit offerings and firm performance. DeGeest et al. (2015) report that motivational HR management practices mediate the relationship between a firm's initial resource base and survival. In addition, a study of the fastest 500 growing entrepreneurial firms in the United States demonstrated that benefits are linked to performance outcomes (Tomczyk et al., 2013). In research exploring the link between employee benefits and firm performance, Lin et al. (2014) find a relationship between the overall strength of the benefit system and organizational performance in a sample of Chinese firms. In addition, within the Taiwanese manufacturing industry, firms offering fringe benefits and retirement funds had lower turnover rates (Lee et al., 2006).

With the exception of the mentioned studies, the link between employee benefit offerings and firm performance is scant. In fact, there is little research on employee benefits programs themselves. We aim to advance knowledge in this area by theoretically and empirically investigating the connection between benefits offerings and new venture survival. 


\section{Theoretical model}

Following the resource-based view of the firm (Barney, 1991), some evidence suggests that firms investing early in valuable, rare, inimitable and non-substitutable resources are able to enhance their survival odds (Doms et al., 1995; Esteve-Perez and Manez-Castillejo, 2008; Hall, 1987). Others have noted that developing legitimacy (Starr and MacMillan, 1990; Zimmerman and Zeitz, 2002), reducing managerial novelty (Shepherd et al., 2000) and improving learning structures (Stinchcombe, 1965) are all important factors in determining firm survival.

In each of these cases, effectively managing HRs is likely to be a key internal element to bettering survival odds (Ensley et al., 2006). To be clear, the HR practices themselves are not likely to serve as a source of competitive advantage, but valuable human capital does (Ployhart et al., 2014; Ployhart and Moliterno, 2011). Internal HR management practices not only provide evidence of business legitimacy to internal and external stakeholders (Zimmerman and Zeitz, 2002), they also help to effectively marshal resources within the firm. Firms that are able to make trade-offs by investing in employee benefits that enhance firm survival odds will be able to more effectively leverage their limited financial and HRs. Allocating resources appropriately in this domain provides an important motivational and legitimacy-enhancing signal to employees and investors that venture management is competent and up to the task of navigating an uncertain environment (Rutherford and Buller, 2007).

New venture leaders must make decisions about HR practices by estimating the extent to which such practices will help the firm attract and retain a valuable workforce (Coff and Kryscynski, 2011). As such, developing legitimacy is a key consideration for new ventures (De Clercq and Voronov, 2009), particularly in their pursuit of high-quality employees (Rutherford and Buller, 2007; Zimmerman and Zeitz, 2002). Individuals with high levels of human capital (i.e. knowledge, skills and abilities) will be less likely to join a firm prior to it establishing some level of legitimacy. Offering employee benefits may be one such way that new ventures can signal legitimacy to potential employees. However, these offerings must be balanced against the significant costs that new ventures are likely to incur by offering extensive employee benefits.

We leverage existing research to hypothesize that employee benefits will affect firm survival through two basic channels. The first channel is 
the costs that offering such a benefit will levy upon the organization. The second channel is through the concept of benefit valence, or the extent to which both employees and potential employees will value a particular benefit. Valence is considered a key aspect of employee motivation (Vroom, 1964), as employees must value a reward before it can stimulate discretionary effort. We apply the concept here to suggest that firms must make choices by balancing the cost of certain benefits with their potential to draw in a higher quality pool of employees and retain this valuable resource. We theorize that certain benefits will be more useful in signaling legitimacy to potential applicants and will be more highly valued by employees, thereby holding the power to attract and retain quality new employees.

In sum, our theoretical model asserts that (a) new ventures are resource constrained and are unable to offer all potential benefits; (b) as such, managers must make strategic choices in resource allocation and (c) managers who choose benefit offerings of higher relative value to the cost incurred will improve the odds of survival. We apply these theoretical assertions below to several specific employee benefit offerings: employee stock options, flexible work arrangements, healthcare, tuition reimbursement, sick days and vacation time.

\section{Benefits enhancing survival}

As highlighted above, existing literature paints a mixed picture of the role that employee benefits play in employee motivation. Benefit valence is an important consideration that differentiates benefits with the potential to attract and retain valuable employees from those with little power to influence employee and applicant choices. Furthermore, we note that the ability of benefits to improve survival outcomes is dependent upon their ability to attract employees with the requisite ability and motivation to produce outputs that are greater than the cost of implementing the benefit program.

The first category of employee benefits likely to affect firm survival are those that offer high valence, with relatively low levels of cost, particularly costs in the short term. As new ventures are likely to be resource constrained, conserving cash and managing cash flow become paramount concerns (Lai et al., 2016; Welsh and White, 1981). Therefore, costly employee benefits will be less advantageous. However, the 
firm will likely gain from benefits that are perceived as valuable by employees, but require relatively little upfront cost. In particular, we focus upon employee stock option plans and flexitime arrangements.

Employees stock ownership plans (ESOPs) offer employees the opportunity to purchase stock in the company at a predetermined rate. ESOPs are attractive as they help to build a mindset of ownership within the employee base by aligning agent behavior with owner expectations (Pendleton, 2006; Poutsma et al., 2012), but require little upfront cost (Hand, 2008). Employees who think like owners will require less monitoring, thereby reducing agency costs, and are more likely to be committed to the success of the organization. While research on employee stock options offers mixed results, such programs tend to have the biggest impact on smaller or moderately sized ventures (Kim and Ouimet, 2014; Rosen and Quarrey, 1987; Welbourne and Andrews, 1996). Employees in such firms have a much clearer line of sight linking their efforts and performance to the success of the firm. While employees in larger firms might have a difficult time seeing how their performance contributes to the stock price of the firm, those in smaller firms will be much more likely to feel like a part of the team and understand their efforts help drive performance.

Finally, as valence pertains to the value of the reward, an appreciating option will mean increased financial value for an employee. It bears noting that the day-to-day motivational value of the benefit will vary based on the current market value of the options. At any point in time, the ESOP may or may not be motivating, per se, but we would expect that in the main offering ESOPs send a valuable signal to the labor market. ESOPs serve as a signal of legitimacy to potential employees and offer current employees the ability to directly benefit from their inputs. If an individual does well and improves the performance of the firm, they will benefit financially. This is likely to be perceived positively by potential employees, helping the firm to draw a wider pool of applicants and build a stronger group of employees. Therefore, theoretically, ESOPs ought to work well in new ventures, spurring individuals to offer significant commitment and engagement to the success of the firm. The associated low administrative costs mean that ESOPs motivational returns ought to exceed the costs of implementation, thereby leading to a positive relationship with new venture survival. 
H1a. New ventures offering ESOPs will be more likely to survive over time.

A second type of employee benefit that is likely to enhance firm survival is flexible work plans. One of the competitive advantages available to newer firms is the opportunity to be more nimble (Kotha et al., 2011). While employees may not be receiving the level of pay they would garner at more established businesses (Balkin and Gomez-Mejia, 1987), these challenges can be offset both by the work offered by new ventures and by the flexible arrangements that might be available. Offering flextime to employees has been linked to lower intent to turnover, lower absenteeism and improved job satisfaction (Narayanan and Nath, 1982; Pierce and Newstrom, 1983).

Many prospective employees, particularly younger people, may bristle at the prospect of working set or standard hours (Ehrhart et al., 2012; Twenge, 2010). Rather, such employees will likely prefer the autonomy and flexibility of completing work within the framework of the day that they arrange. Indeed, many tech firms utilize such employment arrangement as a significant benefit to employees. Offering such programs in concert with challenging goals is more likely to result in successful outcomes.

In addition to younger workers, offering flexibility in work is a useful avenue to attract nontraditional employees who have demands outside of work that need to be kept in consideration. For instance, people with young families may be interested in the increased flexibility they are availed at a new venture. Even older workers who have retired or are looking for a new challenge in the latter stages of their career may find the flexible work arrangements, combined with the excitement of a young firm, to be an attractive combination. Therefore, we expect flexible work arrangements to be a high-valence benefit.

Similar to ESOPs, offering flexible work arrangements comes at a relatively small cost to employers. Notably, offering flexibility and autonomy in work is relatively inexpensive (Coff and Kryscynski, 2011). While there may be some coordination challenges, in general, flexible work programs come with very few administrative costs or ongoing payouts. At the same time, flexible work schedules will likely be viewed as a positive signal by employees. Employees self-selecting into a new venture will likely be looking for work arrangements that differ from those found 
in large, established firms. Most importantly, flexibility in more autonomous work arrangements may be critical in the recruitment and retention of 'superstar' employees, those in the tail of the distribution who produce a disproportionate amount of output. These employees have such a great impact on the fate of the firm that employers will often create iDeals - idiosyncratic deals - to be as flexible as possible in order to keep a superstar content (Aguinis and O'Boyle, 2014). Having found such a flexible model, all employees will likely value (i.e. high valence) the benefit, thereby aiding the firm in attracting and retaining valuable employees.

$H 1 b$. New ventures offering flextime plans will be more likely to survive over time.

\section{Benefits detrimental to survival}

While certain employee benefits are likely to enhance the survival odds of the firm, it is important to note that they are not all equivalent with respect to cost or valence. Herein we offer a nuanced view of employee benefits. For instance, many employee benefits carry significant costs for new ventures, without significantly improving the ability of the firm to attract and retain employees. Such benefits are likely to come at a significant cost, but may not be as highly valued by employees. We consider two such benefits here: health benefits and tuition reimbursement.

While not all new ventures are in a challenged financial position, a significant percentage of new venture managers and entrepreneurs cite cash flow management as a significant issue for their business (Dunn and Liang, 2015). Consider, for example, that in 2015 in the United States a basic employee health plan cost employers, on average, $\$ 17,545$ per employee (Kaiser/HRET). These costs will either need to come out of the company's profit or will be rolled into the price of the product/service offered. In either case, the firm's competitiveness will be weakened, leading to a lower likelihood of survival.

As a result of the significant price tag associated with offering healthcare benefits (relative to stock ownership or flextime), employers must carefully consider the ability of such programs to attract and retain quality employees. The answer to the question of 'do employees appropriately value healthcare benefits and do these benefits outweigh there 
significant cost?' is difficult to answer. Employees at different lifecycle stages will value healthcare benefits differently and employers have a range of options regarding the type, level and quality of healthcare coverage they will offer. We offer our argument based on extant research and descriptive information, but wish to highlight the fact that much more work is needed to correctly estimate the perceived valence of healthcare coverage, the utility of offering such coverage and the comparative costs of such offerings.

Recent studies in the United States indicate that health insurance is one of the most important benefits that employees seek in an employment relationship (Duchon et al., 2000; O'Brien, 2003; Salisbury and Ostuw, 2000). Furthermore, offering healthcare benefits would clearly be a signal of legitimacy to potential employees. While many have come to expect health insurance and note it to be an important condition for employment, the ability of such plans to actually motivate employee action is relatively weak (Mercer What's Working Survey, 2011). Indeed, some research evidence suggests that there is not a strong economic benefit to employers for offering employee healthcare benefits (Buchmueller, 2000; Pauly, 1997).

Moreover, the value of healthcare benefits in the specific context of new ventures is less clear. While larger employers are likely to suffer from offering fewer benefits, we theorize that new ventures would not be similarly penalized by the labor market. Employees willing to work for new ventures are likely to understand and appreciate the risk that they are taking in working for a less established firm. They are likely to understand that resource constraints will prohibit the firm from initially offering extensive health benefits, with the understanding that they will be more likely to adopt such benefits once a certain level of success is achieved. In particular, if healthcare benefits are not properly valued by employees (i.e. low valence) then such firms are not likely to see a motivational boost in the workforce. ${ }^{1}$ Therefore, we hypothesize:

$H 2 a$. New ventures offering healthcare plans will be less likely to survive over time.

Tuition reimbursement reflects an important benefit offering for many large employers. This benefit allows employees to pursue advanced degrees or specialized knowledge that will benefit them in their 
work roles going forward. Broad studies of tuition reimbursement within the United States indicate that nearly $47 \%$ of companies with more than 20 employees offer some form of tuition reimbursement, though the total amount provided is often capped (Lynch and Black, 1998). Interestingly, most firms seem to utilize tuition reimbursement as a means of recruiting and retaining employees (Cappelli, 2004). This is compelling, because from a human capital perspective one would expect that firms would see tuition reimbursement as a form of general skill enhancement, which is projected to lead to higher levels of turnover (Becker, 1964). Becker's (1964) seminal article draws a sharp line between training in general skills and training in firm-specific skills and notes that the employee, not the employer, should bear the cost of general skills training. Becker argues that the individual employee reaps the benefits (or rents) from investments in general skills training, while both the firm and the employee benefit from firm-specific training.

This view is contrasted with much of the literature in HR development, which focuses on enhancements in POS among employees in firms with tuition reimbursement programs (Bartlett, 2001; Pattie et al., 2006). The empirical research in this area offers a nuanced view of the phenomenon. Manchester (2008) finds that investment in tuition reimbursement leads to higher levels of employee retention. Similarly, Pattie et al. (2006) find that tuition reimbursement increases POS and ultimately lowers turnover intent; however, employees pursuing degrees in other fields are more likely to leave the firm. An additional study notes that employees are more likely to leave the organization once they have completed their graduate degree, though this effect is mitigated if promotions follow degree attainment (Benson et al., 2004).

Given the somewhat equivocal findings in the literature, the question is raised regarding the efficacy of tuition reimbursement programs in new ventures. Simply stated, is the benefit worth the cost? Tuition reimbursement carries a considerable price tag for employers. For instance, the cap for tuition reimbursement is often US\$ 4000-US\$ 5250 per year, per employee (Manchester, 2008). This reflects a significant cost and also provides employees with a new set of skills and a credential (degree) with market value outside of the boundaries of the firm. Therefore, on one hand the overall cost of tuition reimbursement may be increased by turnover and replacement costs. On the other hand, providing training through tuition reimbursement may enhance the skill level 
of employees and also may increase commitment to the firm. Benson et al. (2004) support a contingency model, in which investments in general human capital (knowledge, skills and abilities) endowments trigger potential turnover, unless the degree attainment is swiftly followed by a promotion. Given the relatively small number of levels in a new venture, it may be difficult to promote someone completing an advanced degree. In the case of tuition reimbursement, the new venture may be paying to develop talent for a larger, competing firm. Therefore, in new ventures, it is challenging to see the motivational benefit of offering tuition reimbursement outweighing the sticker price and the risk of turnover.

$H 2 b$. New ventures offering tuition reimbursement plans will be less likely to survive over time.

\section{Common benefits}

A third group of employee benefits are those necessary but probably not sufficient for improving firm survival odds. These are benefits that are not highly valued by employees, causing low valence; however, the absence of these benefits will make it difficult to attract and retain quality employees. In other words, an employee is unlikely to join a firm because of these types of benefits, but will likely not join if the benefits are not in place. Reflecting deeper upon motivation theory, these factors would be considered hygiene factors in Herzberg's (1959) Two Factor Model of motivation. In other words, the absence of hygiene factors is dissatisfying to employees, but the presence of these factors does not motivate performance (Herzberg, 1959). While employees in new ventures are likely to understand the lack of extensive healthcare coverage or tuition reimbursement, there are certain benefits that will be expected, namely paid sick leave and vacation leave.

While these benefits are expected, they will be unlikely to provide a motivational benefit as employees in the modern era will likely view these as rights of employment. In fact, many practitioners already note that employees view sick leave as an entitlement of employment, with the Department of Labor reporting that $82 \%$ of management and professional workers receive sick pay (Peck, 2015). Similarly, the Bureau of Labor Statistics estimate that $84 \%$ of all employees in the private sector received vacation pay in 2012 , with over $90 \%$ of full-time employees 
reporting that they receive the benefit of paid vacation time (Van Giezen, 2013). These benefits appear to be nearly ubiquitous in the modern workplace, which will make the absence of such benefits problematic for newer firms.

Furthermore, such benefits are relatively inexpensive to offer as compared to health insurance or tuition reimbursement, but would likely lead to recruitment and retention problems should the organization fail to offer such basic staples of the 21st century workplace. Therefore, they would be classified as low-cost/low valence benefit offerings. In other words, while these benefits do not offer a motivational boost, not offering them would be considered a dis-satisfier and may hurt employee motivation. Firms unable to offer these benefits may find it difficult to signal legitimacy to the market place and will be less likely to build the human capital resources necessary for long term success.

H3a. New ventures offering paid sick time will be more likely to survive over time.

$H 3 b$. New ventures offering paid vacation time will be more likely to survive over time.

\section{Methods}

Data

To test the proposed association of individual employee benefits on venture survival, we utilize the US Kauffman Firm Survey (KFS) of newly established firms. Collected by a market research firm for the Kauffman Foundation (one of the largest entrepreneurship-focused philanthropic organizations in the world), the KFS is arguably one of the most comprehensive studies of ventures started in the United States. Beginning with a Dun \& Bradstreet list of 250,000 firms that first began operations in 2004, the market research firm randomly sampled 32,469 ventures. They defined a start-up as any independent business that was established by a single person or a team, or purchased as an existing business or new franchise. Businesses were excluded if they had a federal identification number, income on Schedule C, or paid either federal 
Social Security or state unemployment insurance or taxes prior to 2004 . The initial sample identified 4928 ventures started in 2004 and these ventures were followed over six annual follow-up surveys until 2011.

This panel survey is formed by stratifying the sample based on demographic characteristics of the owners (based on race and sex) or industry membership (high-tech, medium-, or low-tech). We use the confidential KFS data available on the National Opinion Research Centre's (NORC) Data Enclave, a private repository housing restricted access microdata which permits a more fine-grained analysis compared to the data available to the public. Specifically, we use the survival analysis file developed by Farhat and Robb (2014). ${ }^{2}$ For more detailed information on the inception, collection and dissemination of the KFS, we refer the interested reader to the KFS website (Source: http://www.kauffman.org/ what-we-do/research/kauffman-firm-survey-series ) and other studies that have used the KFS Enclave data (Cassar, 2014).

We control for a variety of factors to lower the influence of un-observable effects, specifically firm performance, location and ownership characteristics. While excluding many controls would lead to a substantially larger sample size, the inferences may not be robust to controlling for a variety of venture-related characteristics. Without applying any filters to the data, based on case-wise deletion, our final sample includes a panel of 1012 ventures.

\section{Outcome variable}

Consistent with extant conceptual and empirical studies of entrepreneurship, our outcome of interest is firm survival (Ucbasaran et al., 2003; Wennberg et al., 2010). The outcome variable is a censored variable indicating if a venture has failed $=1$, else coded as censored. In the sample, of the 1012 ventures, 656 were coded as failed, representing a $64.82 \%$ failure rate.

\section{Predictors}

The respondents were asked whether they offered 'stock options or stock ownership plans', 'Alternative work schedules such as flex time or job sharing', 'A health insurance plan either through the business or an association', 'Tuition reimbursement', 'paid sick days', or 'paid vacation', 
to their full-time employees. If a venture provided a benefit, it was coded $1=$ Yes, else it was coded $0=$ No.

\section{Controls}

As race diversity and gender diversity could lead to distinct venture decisions, processes and subsequent performance (Andrevski et al., 2014; Robb and Watson, 2012), we include Blau's diversity indices for race and gender. The race included in the measure are American Indian, Asian, Black, Hispanic, Other and White. As survival rates vary by sector, we include whether a venture is in the high-tech sector (Colombo et al., 2014).

Relationships with the stakeholders in the task environment are critical to venture survival (Cennamo et al., 2012). We include payment practices (variable name in the data: paysc), which is a dollar-weighted measure of payment performance to suppliers based on data reported in the Dun and Bradstreet (D\&B) database. The score ranges from 1 to 100 with lower values indicating poorer payment performance.

The number of active owners, total employees (sum of full-time and part-time employees), number of locations, whether a venture provides product $(=1$, else $=0)$ or service $(=1$, else $=0$; reference category providing both product and service) could also influence the likelihood of survival (Millan et al., 2012; Nambisan and Baron, 2013). We also include whether the venture has Internet sales $(=1$, else $=0)$ as such ventures may have distinct strategic and resource management processes. First owner has equity ownership $(=1$, else $=0$ ) and the first owner's amount of equity ownership (percentage) are important additional controls that could affect a venture's resource allocation (Kotha and George, 2012). We control for net profit loss amount, equity and liabilities that could proxy for unobservables driving venture failure. Finally, we include whether the primary owner is a paid employee $(=1$, else $=0)$. As location could affect firm performance (Baum and Mezias, 1992), we also control for state dummies.

\section{Results}

Table 1 lists mean, standard deviation and pairwise correlations based on case-wise deletions. We use Cox regression to test the proposed hypotheses (Burbidge et al., 1988; Moss et al., 2015). 


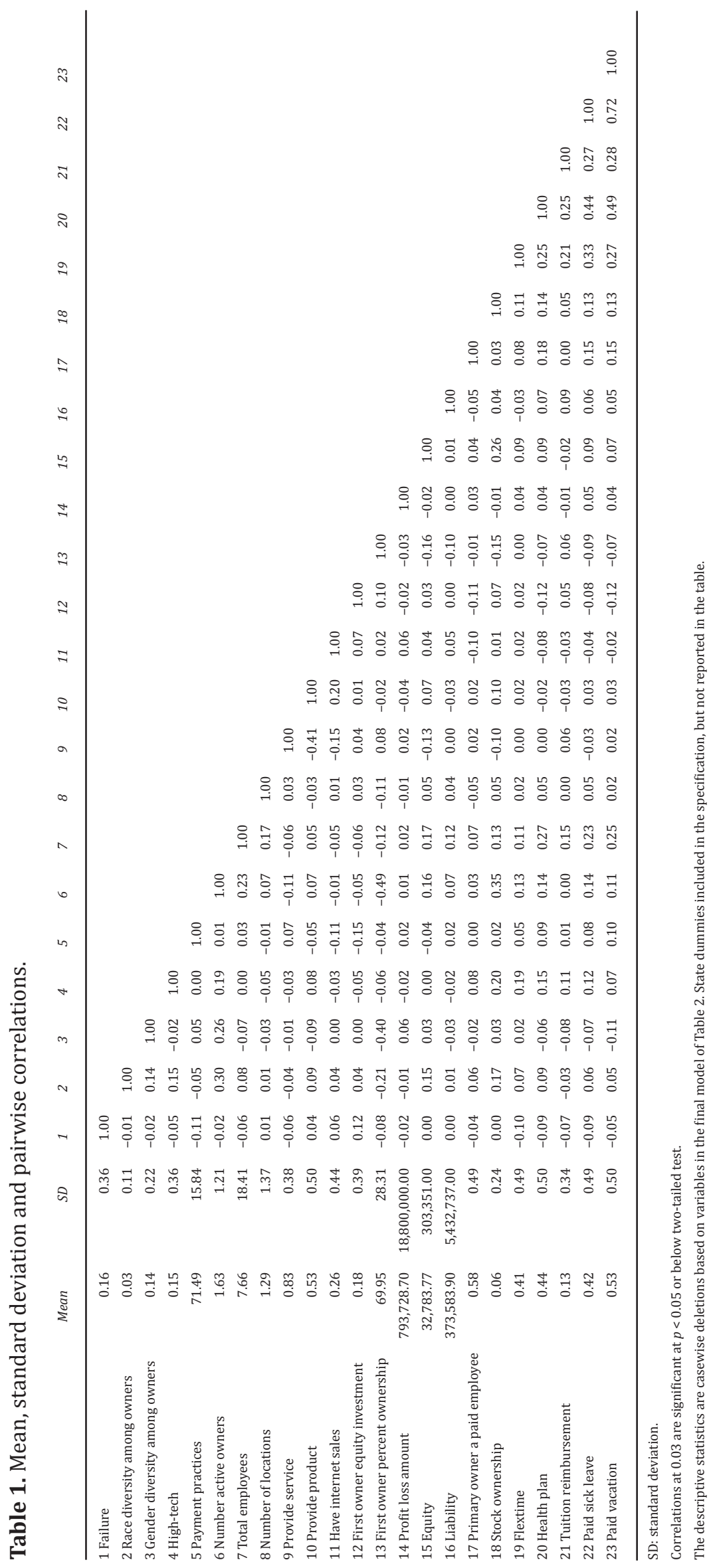




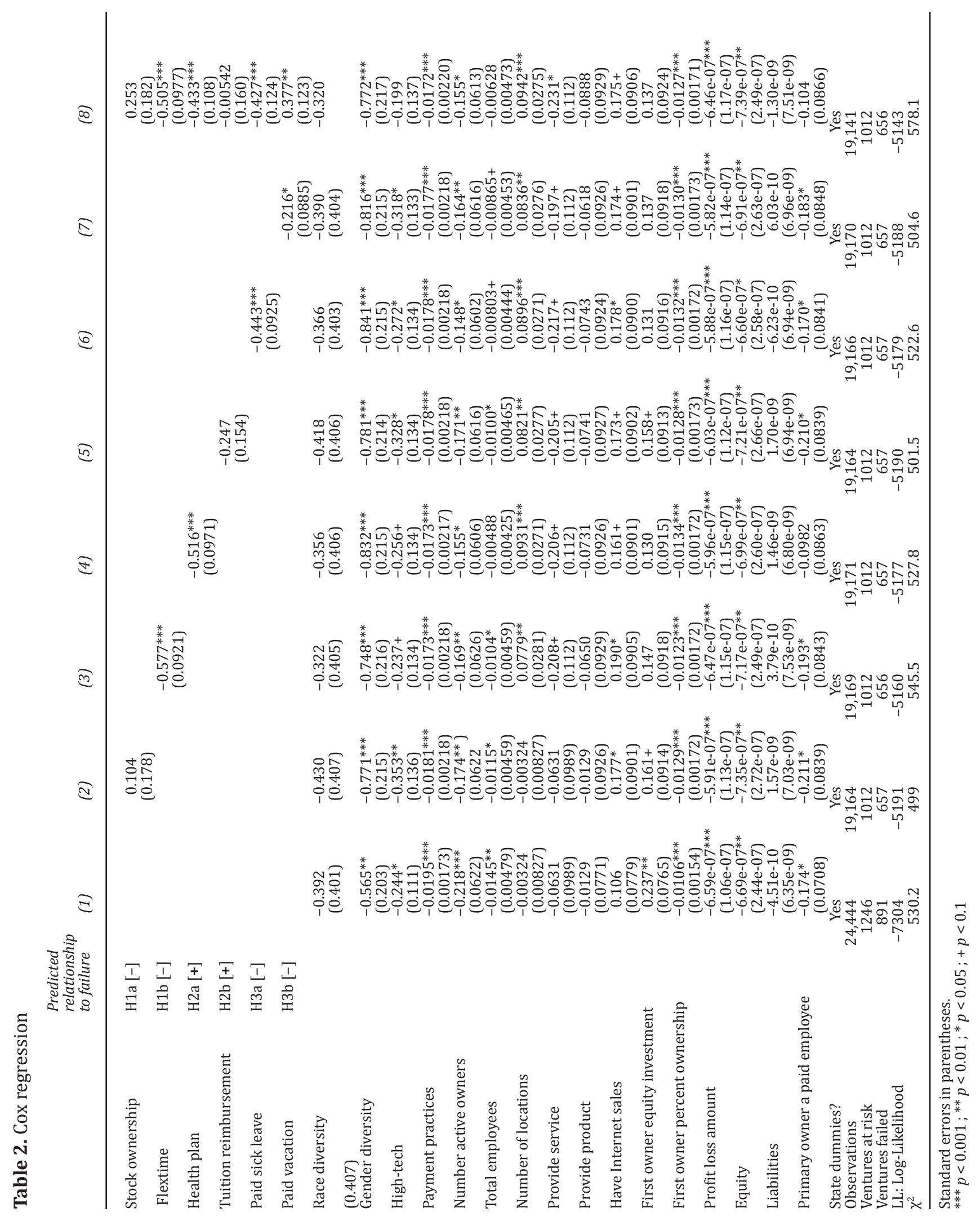


Hypothesis $1 \mathrm{a}$ argues that offering stock ownership plans will positively affect survival odds, but is not supported in the model (Model 2: H1a: $\beta=0.104, p>0.10$ ). Despite the non-significance of the findings we sought to explore the direction of effects. Figure 1(a) shows that ventures with stock ownership have a higher likelihood of failure. H1b proposed that new ventures offering flextime will be more likely to survive (Model 3: H1b: $\beta=-0.577, p<0.001$ ), and is supported in the predicted direction (Figure 1(b)).

Hypothesis 2 a proposed that new ventures offering a healthcare plan were less likely to survive (Model 4: H2a: $\beta=-0.516, p<0.001$; Figure $1(\mathrm{c})$ ). Based on Figure 1c health plans lowered the likelihood of failure, and therefore, $\mathrm{H} 2 \mathrm{a}$ is not supported and the effects are in the opposite of the predicted direction. Hypothesis $2 \mathrm{~b}$ proposed that new ventures offering tuition reimbursement were less likely to survive and is not supported (Model 5: H2b: $\beta=-0.247, p>0.10$; Figure $1(\mathrm{~d})$ ). Hypothesis 3a (Model 6: $\beta=-0.443, p<0.001$; Figure $1(\mathrm{e})$ ) related to paid sick leave was significant and Hypothesis $3 b\left(\beta=-0.216, p<0.001\right.$; Figure $1(\mathrm{f})^{3}$ related to paid vacation was significant.

Overall, hypotheses $1 \mathrm{a}$ and $2 \mathrm{~b}$ are not supported, $\mathrm{H} 2 \mathrm{a}$ is not supported but is significant in the opposite direction and hypotheses $1 \mathrm{~b}$, $3 \mathrm{a}$ and $3 \mathrm{~b}$ are supported. The results broadly suggest that stock ownership or tuition reimbursement have no influence on survival, whereas, flextime, health plan, paid sick leave or vacation offerings lower the hazard of failure.

\section{Discussion}

During early stages of venture development, attracting and retaining employees is the foundation of developing human capital related capabilities. However, providing extensive employee benefits could increase costs, have limited benefits during early stages, and at times increase the odds of failure. This article utilizes a unique panel dataset to assess the extent to which a variety of employee benefits offerings enhance or inhibit firm survival. The results of this article indicate that firms offering flexible work arrangements, health plans, paid vacation days and paid sick leave improved survival odds, while firms offering stock ownership or tuition reimbursement realize no improvement in survival odds. 
(a)

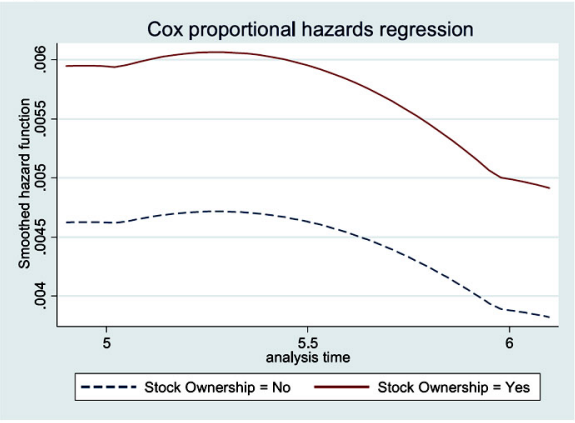

(c)

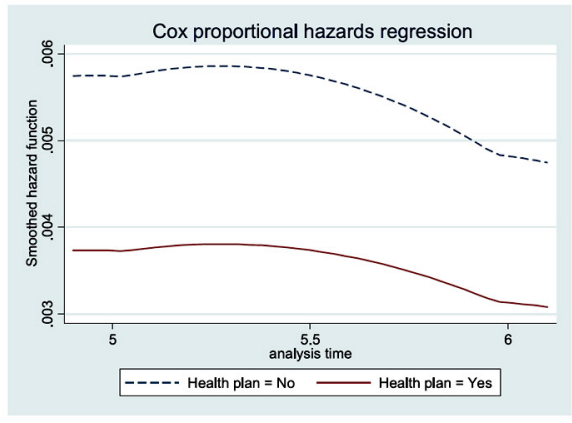

(e)

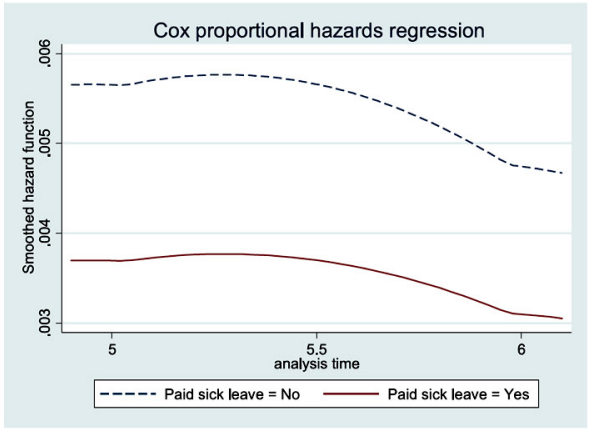

(b)

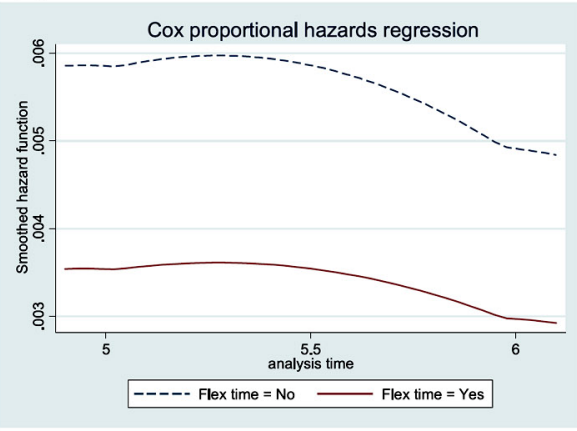

(d)

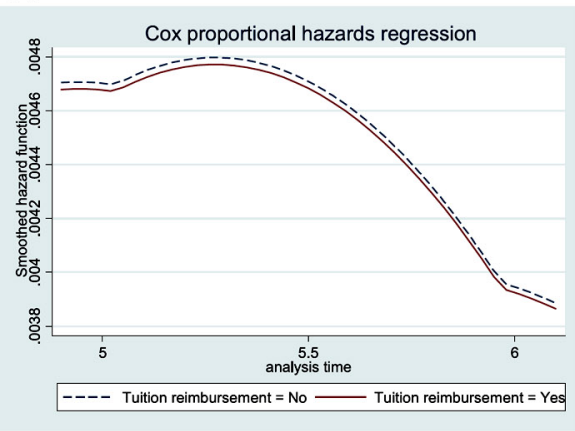

(f)

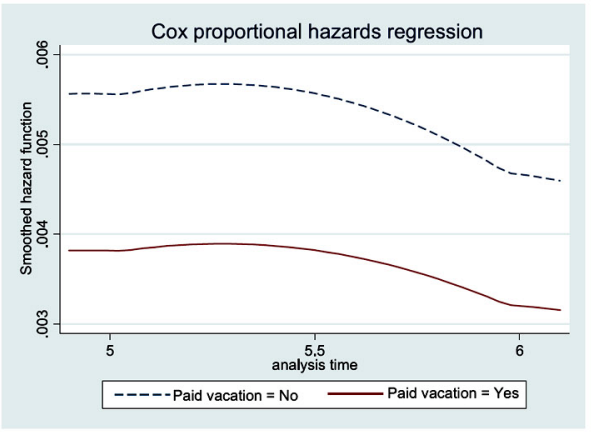

Figure 1. Survival effects of (a) stock ownership, (b) Flextime, (c) health plan (d) tuition reimbursement (e) paid sick leave and (f) paid vacation.

Employee benefits represent an important tool for ventures to attract and retain talent (Klaas et al., 2000; Williams and Dreher, 1992). The results of this article support the need to understand both the costs and returns that employee benefits are expected to provide. Under the guidance of existing theories of motivation (Vroom, 1964) we argue that in order for a benefit to have a positive effect, it must be valued (i.e. 
valence) by employees. If a benefit is simply expected as an entitlement of employment, or is similarly not perceived to be useful by employees, then that benefit is unlikely to yield a return for the organization. Yet, if new ventures are able to invest in employee benefits that carry a relatively small price tag, but retain the potential to motivate employees, then such benefits are likely to have a positive effect on firm performance and survival.

The results of this article partially support this conceptual argument. In particular, it appears that new ventures benefit from offering flexible work arrangement to employees. New ventures may be able to benefit by offering a more informal work space where employees are encouraged to set-up their schedules in a manner that fits their lifestyle. This may create a strong employer brand for non-traditional employees, or younger employees who may be more willing to exchange higher salaries for greater flexibility. The flexibility serves as a positive signal to the labor market, helping the firm to attract and retain quality employees. This allows the new venture, in the parlance of De Clercq and Voronov (2009) to both 'fit in and stand out' to build legitimacy.

The finding that healthcare benefit offerings are correlated with higher survival odds is an important finding both practically and theoretically. Many employees seek out employers with strong healthcare offerings and new ventures offering healthcare seem to be at a survival advantage. This finding runs counter to the hypothesized expectation and may demonstrate that healthcare coverage is becoming a significant concern for employees across a broad spectrum of organizations. While these employees still may not truly understand or appreciate the finer points of the employer-sponsored plan, having the plan in place may be enough to offer signaling and retention benefits that help firms to overcome the significant costs associated with the plan. In other words, healthcare benefits may not be motivating, but they may be an important signal of legitimacy that helps to sort higher level human capital into the firm. Alternatively, it may be that the absence of healthcare is a significant dis-satisfier to many employees, such that offering a plan is a necessary condition for attracting high-quality employees. Furthermore, rising costs and the increased media and policy attention on healthcare has likely raised this issue to the attention of employees. Regardless, future work is necessary to determine the sorting effects of healthcare. Similarly, higher odds of survival associated with paid sick leave 
and paid vacation suggest that paid days off could be a recruitment and retention tool.

The findings on the association between offering healthcare plans and new venture survival is also relevant to recent policy debates, particularly in the United States. While the debate surrounding the Affordable Care Act (ACA) continues, businesses are faced with making difficult economic choices regarding the types of benefits that they are willing, or are compelled, to offer. While the ACA provisions do not apply to ventures with fewer than 50 employees, those that exceed this threshold will be expected to provide health insurance benefits to their employees. This has several ramifications for new venture managers. First, it may be that investing early in healthcare programs helps to build legitimacy to set the business apart from other competitors with fewer than 50 employees. While this is a costly strategy for firms to take, it may lead to an advantage in acquiring human capital in the early stages of venture growth. Second, it suggests that once the employee limit is reached, offering health insurance will not place the business at a cost disadvantage, as competitors will face similar regulations. Clearly more research is needed to best understand this relationship and the inflection point at which offering health insurance benefits no longer offer a human capital return, but this article offers preliminary evidence that health insurance is not detrimental to survival.

Interestingly, this article did not find a positive effect for firms offering stock ownership. This finding runs counter to much existing scholarship on ESOPs (Cardon and Stevens, 2004). Given the nature of ESOP in reducing agency costs and promoting ownership via relatively small costs, it was expected that firms offering ESOPs would have better survival rates. However, the results of the analysis indicate that the opposite is true. This may add further support to research indicating that ESOPs may not always be valuable. For instance, a recent study highlights that ESOPs may lead to entrenchment strategies and cause small firms to invest less in innovation through research and development (Gamble, 2000). This article highlights the fact that risk aversion on the part of employees who have now become managers, leads to less risk-taking. Future work is necessary to theoretically and empirically examine the role of ESOPs in management decision-making, risk-taking and ultimately in delivering returns to shareholders, including the employees. It is likely that important contextual features are influential regarding 
the value of ESOPs to new venture survival and performance. It may be that certain industries, such as high-tech may benefit from ESOPs, while firms in less human capital intensive industries may not benefit from offering stock option plans. Additional work on these important moderating influences is needed.

Taken more broadly, the results of this article fit within existing discussions of employment practices in new ventures and in smaller firms (Cardon, 2003; Lai et al., 2017; Messersmith and Wales, 2011; Verreynne et al., 2011). Research in this area is beginning to develop a deeper understanding of the role that HR systems may play in helping to build stronger human capital resources. This article adds an additional element to this discussion to better understand the tradeoffs between employment costs and the benefits incurred by various practices. For those firms seeking an incremental approach, this article offers guidance on which practices to first make investments in and which to delay until firmer footing is secured. We call for additional research to continue to explore the temporal nature of benefit practice adoption, with a more nuanced understanding of the trade-offs between costs and benefits.

This article also offers a broader framework by which to judge investments in HR management practices in early-stage ventures. While entrepreneurs and new business owners are likely conversant with costbenefit analysis, it can often be difficult to measure the 'benefit' of HR practices and policies. This findings stresses the importance of the motivational and signaling properties of practices that help to attract and retain quality employees. Focusing exclusively on the initial cost of investing in employee benefits may be short sighted in terms of the development of human capital resources within the firm.

While we did not complete an in-depth utility analysis, this does set the stage for future work that might more readily quantify the benefit of certain employment practices. This specifically asks new venture managers to weigh the ability of a practice to signal legitimacy to help sort in quality employees and also to better understand the valence of the benefits offered. These factors need to be meaningfully combined and weighed against the cost of implementing new practices. We have taken a first step in this direction, but more refined work in the future would be able to assess the true economic value of human capital in new ventures and the practices that help to build this critical resource. 
Finally, this article also contributes to a broader discussion regarding the role and effect of implementing HR practices in small and new firms (i.e. Cardon and Stevens, 2004; Chadwick et al., 2013; Messersmith and Wales, 2011; Way, 2002). Ultimately new ventures must make critical strategic choices regarding where and when to invest their limited tangible and intangible resources (Chadwick et al., 2013). Chadwick et al. (2013) highlight the burden that administering HR systems may place on the critical resource of managerial attention. Managing employee benefits may constrain the time and attention of new venture managers, raising the importance of making wise selections in determining which HR practices to implement. In sum, this article contributes to a broader stream of studies in HR management that seeks to understand both the costs of implementing HR systems in new ventures and the benefits that firms are likely to accrue from these systems.

\section{Limitations and conclusion}

While this article has a number of strengths, there are still several limitations that need to be considered when evaluating the results. While we theorize about benefit valence and the ability of certain practices to attract high-quality employees relative to their perceived cost, we were unable to directly measure employee valence in regard to specific benefits. While we expect that the ability to attract employees, and the quality of those applicants attracted to the new venture is a main causal link between the benefits offered and the outcomes achieved, we were unable to directly measure this in this article. Further investigation is necessary to determine if the theoretical linkages presented above remain empirically valid. This is especially important given the equivocal nature of the findings.

In addition, this article is based on new ventures based in the United States. The benefits context will likely vary dramatically based on the employee policies of a given country. While the underlying theory underpinning the model is likely to translate, the results of this article may not readily generalize to contexts where more benefits are required to be offered or where certain benefits are offered by the state rather than through employers. Additional research is needed beyond the US context to test the external validity of the findings.

It is also important to note that while benefit valence is likely to generalize to many employees, individual perceptions will vary (Coff and 
Kryscynski, 2011). One employee's valued benefit may not 'move the needle' for another employee. Again, we argue in the main and consider this to be a firm-level study, but future work is needed at the individual level to tease out these effects. In addition, we focus on a relatively small number of employee benefits. Additional employee benefits should also be considered in future research.

This article also relies upon data that are largely binary in nature, with the presence or absence of an employee benefit being the primary measure. While this provides evidence of a benefit's existence, it does not tell the full story of implementation scope. Future investigations focused more heavily on implementation are necessary to continue to advance knowledge in this domain.

In conclusion, making important investment decisions in regard to human capital is an important stepping-stone in the path of survival and growth for new ventures. This article highlights the potential motivational properties, as well as, the costs of popular employee benefit offerings. The results support a differentiated approach where new venture managers are well served by investing in policies with high motivational potential, but relatively low near-term costs. In other words, firms that make wise trade-offs in employee benefit offerings will benefit by receiving greater 'bang for the buck'.

Acknowledgments The authors thank the editor, Professor Claire Leitch, and the two anonymous referees for their excellent comments and suggestions.

Funding Portions of this research received financial support from Ewing Marion Kauffman Foundation.

\section{Notes}

1. It bears noting that the data for this article was sampled prior to the full implementation of the Affordable Care Act (ACA) in the United States. This significant chance in the regulatory environment is likely to have consequences that are beyond the scope of this article, but are worthy of future consideration when the provisions of the ACA have been fully implemented.

2. The file name is 'Longitudinal_Long_MI_Survival_Ready.dta'.

3. Although the direction of effect changes from model 7 to model 8 for the effect of paid vacation, it possibly may be due to shared correlation among the practices. All the remaining figures are plotted based on estimates from the model 8, except for Figure 2(f), which is plotted based on estimates from model 7. 


\section{References}

Aguinis H and O'Boyle EH (2014) Star performers in twenty-first-century organizations. Personnel Psychology 67(2): 313-350.

Andrevski G, Richard OC, Shaw JD, et al. (2014) Racial diversity and firm performance: The mediating role of competitive intensity. Journal of Management 40(3): 820-844.

Bai Y, Yuan J and Pan J (2017) Why SMEs in emerging economies are reluctant to provide employee training: Evidence from China. International Small Business Journal 35(6): 751-766. DOI: 10.1177/0266242616682360.

Balkin DB and Gomez-Mejia LR (1987) Toward a contingency theory of compensation strategy. Strategic Management Journal 8(2): 169-182.

Barney J (1991) Firm resources and sustained competitive advantage. Journal of Management 17(1): 99-120.

Bartlett KR (2001) The relationship between training and organizational commitment: A study in the health care field. Human Resource Development Quarterly 12(4): 335-352.

Baum JA and Mezias SJ (1992) Localized competition and organizational failure in the Manhattan hotel industry, 1898-1990. Administrative Science Quarterly 37(4): 580-604.

Benson GS, Finegold D and Mohrman SA (2004) You paid for the skills, now keep them: Tuition reimbursement and voluntary turnover. Academy of Management Journal 47(3): 315-331.

Blau G, Merriman K, Tatum DS, et al. (2001) Antecedents and consequences of basic versus career enrichment benefit satisfaction. Journal of Organizational Behavior 22(6): 669-688.

Buchmueller TC (2000) The Business Case for Employer-provided Health Benefits: A Review of the Relevant Literature. Oakland, CA: HealthCare Foundation.

Burbidge JB, Magee L and Robb AL (1988) Alternative transformations to handle extreme values of the dependent variable. Journal of the American Statistical Association 83(401): 123-127.

Cappelli P (2004) Why do employers pay for college? Journal of Econometrics 121(1): 213-241.

Cardon MS (2003) Contingent labor as an enabler of entrepreneurial growth. Human Resource Management 42(4): 357-373.

Cardon MS and Stevens CE (2004) Managing human resources in small organizations: What do we know? Human Resource Management Review 14: 295-323.

Cassar G (2014) Industry and startup experience on entrepreneur forecast performance in new firms. Journal of Business Venturing 29(1): 137-151.

Caves RE (1998) Industrial organization and new findings on the turnover and mobility of firms. Journal of Economic Literature 36: 1947-1982.

Cennamo C, Berrone P, Cruz C, et al. (2012) Socioemotional wealth and proactive stakeholder engagement: Why family-controlled firms care more about their stakeholders. Entrepreneurship Theory and Practice 36(6): 1153-1173. 
Chadwick C, Super JF and Kwon K (2015) Resource orchestration in practice: CEO emphasis on SHRM, commitment-based HR systems, and firm performance. Strategic Management Journal 36(3): 360-376.

Chadwick C, Way SA, Kerr G, et al. (2013) Boundary conditions of the highinvestment human resource systems - Small firm labor productivity relationship. Personnel Psychology 66: 311-343.

Coff R and Kryscynski D (2011) Drilling for micro-foundations of human capitalbased competitive advantages. Journal of Management 37: 1429-1443.

Colombo MG, Croce A and Murtinu S (2014) Ownership structure, horizontal agency costs and the performance of high-tech entrepreneurial firms. Small Business Economics 42(2): 265-282.

Danehower C and Lust JA (1995) Understanding and measuring employee benefit satisfaction. Benefits Quarterly 11(1): 69.

De Clercq D and Voronov M (2009) Toward a practice perspective of entrepreneurship entrepreneurial legitimacy as habitus. International Small Business Journal 27(4): 395-419.

DeGeest DS, Follmer EH, Walter SL, et al. (2015) The benefits of benefits: A dynamic approach to motivation- enhancing human resource practices and entrepreneurial survival. Journal of Management. Epub ahead of print 29 January. DOI: $10.1177 / 0149206315569313$.

Delmar F and Shane S (2003) Does business planning facilitate the development of new ventures? Strategic Management Journal 24(12): 1165-1185.

Delmar F and Shane S (2004) Legitimating first: Organizing activities and the survival of new ventures. Journal of Business Venturing 19(3): 385-410.

Doms M, Dunne T and Roberts MJ (1995) The role of technology use in the survival and growth of manufacturing plants. International Journal of Industrial Organization 13(4): 523-542.

Duchon L, Schoen C, Simantov E, et al. (2000) Listening to Workers: Findings from the Commonwealth Fund 1999 National Survey of Workers' Health Insurance. New York: The Commonwealth Fund.

Dunn P and Liang CLK (2015) Fallacies versus realities in financial planning and management among entrepreneurs: Lessons from the trenches. Journal of Small Business Strategy 13(1): 95-104.

Ehrhart KH, Mayer DM and Ziegert JC (2012) Web-based recruitment in the millennial generation: Work-life balance, website usability, and organizational attraction. European Journal of Work and Organizational Psychology 21(6): 850-874.

Ensley MD, Hmieleski KM and Pearce CL (2006) The importance of vertical and shared leadership within new venture top management teams: Implications for the performance of startups. The Leadership Quarterly 17(3): 217-231.

Esteve-Perez S and Manez-Castillejo JA (2008) The resource-based theory of the firm and firm survival. Small Business Economics 30(3): 231-249.

Farhat J and Robb A (2014) Applied survey data analysis using stata: The Kauffman Firm Survey data. Available at: https://papers.ssrn.com/sol3/papers. cfm?abstract id $=2477217$ 
Gamble JE (2000) Management commitment to innovation and ESOP stock concentration. Journal of Business Venturing 15(5): 433-447.

Hall BH (1987) The relationship between firm size and firm growth in the U.S. manufacturing sector. The Journal of Industrial Economics 35: 583-606.

Hand JR (2008) Give everyone a prize? Employee stock options in private venturebacked firms. Journal of Business Venturing 23(4): 385-404. Available at: http:// www.hhs.gov/healthcare/about-the-law/read-the-law/index.html (accessed 1 February 2017).

Hannan MT and Freeman J (1989) Organizational Ecology. Cambridge, MA: Harvard University Press.

Herzberg F (1959) The Motivation to Work. NewYork: John Wiley \& Sons.

Hong JC, Yang SD, Wang LJ, et al. (1995) Impact of employee benefits on work motivation and productivity. International Journal of Career Management 7(6): 10-14.

Huselid MA (1995) The impact of human resource management practices on turnover, productivity, and corporate financial performance. Academy of Management Journal 38(3): 635-672.

Ingley C, Khlif W and Karoui L (2017) SME growth trajectories, transitions and board role portfolios: A critical review and integrative model. International Small Business Journal 35(6): 729-750. DOI: 10.1177/0266242616680280.

Jiang K, Lepak DP, Hu J, et al. (2012) How does human resource management influence organizational outcomes? A meta-analytic investigation of mediating mechanisms. Academy of Management Journal 55(6): 1264-1294.

Kim E and Ouimet P (2014) Broad-based employee stock ownership: Motives and outcomes. The Journal of Finance 69(3): 1273-1319.

Klaas BS, McClendon J and Gainey TW (2000) Managing HR in the small and medium enterprise: The impact of professional employer organizations. Entrepreneurship: Theory and Practice 25(1): 107-107.

Ko J and Hur S (2014) The impacts of employee benefits, procedural justice, and managerial trustworthiness on work attitudes: Integrated understanding based on social exchange theory. Public Administration Review 74(2): 176-187.

Koryak O, Mole KF, Lockett A, et al. (2015) Entrepreneurial leadership, capabilities and firm growth. International Small Business Journal 33(1): 89-105.

Kotha R and George G (2012) Friends, family, or fools: Entrepreneur experience and its implications for equity distribution and resource mobilization. Journal of Business Venturing 27(5): 525-543.

Kotha R, Zheng Y and George G (2011) Entry into new niches: The effects of firm age and the expansion of technological capabilities on innovative output and impact. Strategic Management Journal 32(9): 1011-1024.

Lai Y, Saridakis G and Johnstone S (2017) Human resource practices, employee attitudes and small firm performance. International Small Business Journal 35(4): 470-494. DOI: $10.1177 / 0266242616637415$.

Lai Y, Saridakis G, Blackburn R, et al. (2016) Are the HR responses of small firms different from large firms in times of recession? Journal of Business Venturing 31(1): 113-131. 
Lee CH, Hsu ML and Lien NH (2006) The impacts of benefit plans on employee turnover: A firm-level analysis approach on Taiwanese manufacturing industry. The International Journal of Human Resource Management 17(11): 1951-1975.

Leitch C, Hill F and Neergaard H (2010) Entrepreneurial and business growth and the quest for a 'comprehensive theory': Tilting at windmills? Entrepreneurship Theory and Practice 34: 249-260.

Lin Z, Yao X and Zhao Z (2014) The direct and indirect impact of employee benefits on firm performance in China. Asia Pacific Journal of Human Resources 52(4): 476-495.

Lynch LM and Black SE (1998) Beyond the incidence of employer-provided training. ILR Review 52(1): 64-81.

Manchester CF (2008) The effect of tuition reimbursement on turnover: A case study analysis. In: The Analysis of Firms and Employees: Quantitative and Qualitative Approaches. Chicago: University of Chicago Press, pp. 197-228.

Mercer What's Working Survey (2011). Available at: http://www.shrm.org/ hrdisciplines/benefits/articles/pages/motivationkey.aspx

Messersmith JG and Guthrie JP (2010) High performance work systems in emergent organizations: Implications for firm performance. Human Resource Management 49(2): 241-264.

Messersmith JG and Wales WJ (2011) Entrepreneurial orientation and performance in young firms: The role of human resource management. International Small Business Journal 23: 115-136.

Millan JM, Congregado E and Roman C (2012) Determinants of self-employment survival in Europe. Small Business Economics 38(2): 231-258.

Moss TW, Neubaum DO and Meyskens M (2015) The effect of virtuous and entrepreneurial orientations on microfinance lending and repayment: A signaling theory perspective. Entrepreneurship Theory and Practice 39(1): 27-52.

Muse LA and Wadsworth LL (2012) An examination of traditional versus nontraditional benefits. Journal of Managerial Psychology 27(2): 112-131.

Nambisan S and Baron RA (2013) Entrepreneurship in innovation ecosystems: Entrepreneurs' self-regulatory processes and their implications for new venture success. Entrepreneurship Theory and Practice 37(5): 1071-1097.

Narayanan VK and Nath R (1982) A field test of some attitudinal and behavioral consequences of flexitime. Journal of Applied Psychology 67(2): 214.

O’Brien E (2003) Employers' benefits from workers' health insurance. Milbank Quarterly 81(1): 5-43.

Pattie M, Benson GS and Baruch Y (2006) Tuition reimbursement, perceived organizational support, and turnover intention among graduate business school students. Human Resource Development Quarterly 17(4): 423-442.

Pauly MV (1997) Health Benefits at Work: An Economic and Political Analysis of Employment-based Health Insurance. Ann Arbor, MI: University of Michigan Press.

Peck E (2015) Paid sick leave is fast becoming a right - Not a privilege. Huffington Post Business, 8 September. Available at: http://www.huffingtonpost.com/entry/ companies-paid-sick-leave_us 55 ef2fa7e4b002d5c076eb85 
Pendleton A (2006) Incentives, monitoring, and employee stock ownership plans: New evidence and interpretations. Industrial Relations: A Journal of Economy and Society 45(4): 753-777.

Pierce JL and Newstrom JW (1983) The design of flexible work schedules and employee responses: Relationships and process. Journal of Occupational Behaviour: 247-262.

Ployhart RE and Moliterno TP (2011) Emergence of the human capital resource: A multilevel model. Academy of Management Review 36(1): 127-150.

Ployhart RE, Nyberg AJ, Reilly G, et al. (2014) Human capital is dead: Long live human capital resources! Journal of Management 40(2): 371-398.

Poutsma E, Blasi JR and Kruse DL (2012) Employee share ownership and profit sharing in different institutional contexts. International Journal of Human Resource Management 23(8): 1513-1518.

Robb AM and Watson J (2012) Gender differences in firm performance: Evidence from new ventures in the United States. Journal of Business Venturing 27(5): 544-558.

Rosen C and Quarrey M (1987) How well is employee ownership working? Harvard Business Review 65(5): 126-132.

Rutherford MW and Buller PF (2007) Searching for the legitimacy threshold. Journal of Management Inquiry 16(1): 78-92.

Salisbury D and Ostuw P (2000) Value of benefits constant in a changing job environment: The 1999 world at work/EBRI value of benefits survey. EBRI Notes 21: 5-6

Sheehan M (2013) Human resource management and performance: Evidence from small and medium-sized firms. International Small Business Journal 32: 545-570.

Shepherd DA, Douglas EJ and Shanley M (2000) New venture survival: Ignorance, external shocks, and risk reduction strategies. Journal of Business Venturing 15(5): 393-410.

Starr JA and MacMillan IC (1990) Resource cooptation via social contracting: Resource acquisition strategies for new ventures. Strategic Management Journal 11(5): 79-92.

Stinchcombe AL (1965) Social structures and organizations. In: March JG (ed.) Handbook of Organizations. Chicago, IL: Rand McNally, pp.149-193.

Teece DJ, Pisano G and Shuen A (1997) Dynamic capabilities and strategic management. Strategic Management Journal 18(7): 509-533.

Tomczyk D, Lee J and Winslow E (2013) Entrepreneurs' personal values, compensation, and high growth firm performance. Journal of Small Business Management 51(1): 66-82.

Twenge JM (2010) A review of the empirical evidence on generational differences in work attitudes. Journal of Business and Psychology 25(2): 201-210.

Ucbasaran D, Lockett A, Wright M, et al. (2003) Entrepreneurial founder teams: Factors associated with member entry and exit. Entrepreneurship Theory and Practice 28(2): 107-128.

Van Giezen RW (2013) Paid leave in private industry over the past 20 years (bureau of labor statistics). Beyond the Numbers: Pay \& Benefits 2(18). Available at: http:// www.bls.gov/opub/btn/volume-2/paid-leave-in-private-industry-over-the-past20-years.htm 
Verreynne ML, Parker P and Wilson M (2011) Employment systems in small firms: A multilevel analysis. International Small Business Journal 31: 405-431.

Vroom VR (1964) Work and Motivation. New York: Wiley.

Way SA (2002) High performance work systems and intermediate indicators of firm performance within the US small business sector. Journal of Management 28(6): 765-785.

Welbourne TM and Andrews AO (1996) Predicting the performance of initial public offerings: Should human resource management be in the equation?. Academy of Management Journal 39(4): 891-919.

Welsh JA and White JF (1981) A small business is not a little big business. Harvard Business Review 59(4): 18-32.

Wennberg K, Wiklund J, DeTienne DR, et al. (2010) Reconceptualizing entrepreneurial exit: Divergent exit routes and their drivers. Journal of Business Venturing 25(4): 361-375.

Williams ML and Dreher GF (1992) Compensation system attributes and applicant pool characteristics. Academy of Management Journal 35(3): 571-595.

Wright M and Stigliani I (2013) Entrepreneurship and growth. International Small Business Journal 31(1): 3-22.

Zacharakis AL, Meyer GD and DeCastro J (1999) Differing perceptions of new venture failure: A matched exploratory study of venture capitalists and entrepreneurs. Journal of Small Business Management 37(3): 1-14.

Zahra SA, Neubaum DO and El-Hagrassey GM (2002) Competitive analysis and new venture performance: Understanding the impact of strategic uncertainty and venture origin. Entrepreneurship Theory and Practice 27(1): 1-28.

Zimmerman MA and Zeitz GJ (2002) Beyond survival: Achieving new venture growth by building legitimacy. Academy of Management Review 27(3): 414-431.

\section{Authors}

Jake G Messersmith is an Associate Professor of Management at the University of Nebraska-Lincoln. His research interests focus on HR systems and organizational performance.

Pankaj C Patel is an Associate Professor of Management at Villanova University. His research interests are in the areas of innovation and governance.

Christopher Crawford is an Assistant Professor of Strategy and Entrepreneurship at Ohio University in the College of Business. His research on power law distributions and extreme outcomes in entrepreneurship has been published in the domain's premier journals and has been presented in Italy, Norway, Canada, South Korea, and throughout the United States. He is currently working on a new project for the National Science Foundation's Science of Organizations, building models to explain and predict the emergence of outliers in entrepreneurship. 